\title{
Serum Vitamin D Metabolites in Colorectal Cancer Patients Receiving Cholecalciferol Supplementation: Correlation with Polymorphisms in the Vitamin D Genes
}

\author{
Josephia R. Muindi - Araba A. Adjei - Zengru R. Wu • \\ Isabel Olson • Huayi Huang • Adrienne Groman • \\ Lili Tian • Prashant K. Singh • Lara E. Sucheston • \\ Candace S. Johnson • Donald L. Trump • \\ Marwan G. Fakih
}

Received: 5 December 2012 / Accepted: 19 February 2013 / Published online: 28 February 2013

(C) The Author(s) 2013. This article is published with open access at Springerlink.com

\begin{abstract}
Cholecalciferol $\left(\mathrm{D}_{3}\right)$ supplementation results in variable increases in serum $25(\mathrm{OH}) \mathrm{D}_{3}$ levels, however, the influence of genetic polymorphisms on these variable responses is unclear. We measured serum $25(\mathrm{OH}) \mathrm{D}_{3}, 24,25$ $(\mathrm{OH})_{2} \mathrm{D}_{3}, 1,25(\mathrm{OH})_{2} \mathrm{D}_{3}$ and VDBP levels in 50 colorectal cancer (CRC) patients before and during 2,000 IU daily oral $\mathrm{D}_{3}$ supplementation for six months and in 263 archived CRC serum samples. Serum PTH levels and PBMC 24OHase activity were also measured during $\mathrm{D}_{3}$ supplementation. TagSNPs in CYP2R1, CYP27A1, CYP27B1, CYP24A1, $V D R$, and $G C$ genes were genotyped in all patients, and the association between these SNPs and serum vitamin $\mathrm{D}_{3}$ metabolites levels before and after $\mathrm{D}_{3}$ supplementation was analyzed. The mean baseline serum $25(\mathrm{OH}) \mathrm{D}_{3}$ level
\end{abstract}

\footnotetext{
J. R. Muindi $(\bowtie) \cdot$ Z. R. Wu $\cdot$ I. Olson • D. L. Trump •

M. G. Fakih

Department of Medicine, Roswell Park Cancer Institute,

Elm and Carlton Streets,

Buffalo, NY 14263, USA

e-mail: Josephia.muindi@roswellpark.org
}

A. A. Adjei $\cdot$ H. Huang $\cdot$ C. S. Johnson

Department of Pharmacology and Therapeutics,

Roswell Park Cancer Institute, Elm and Carlton Streets,

Buffalo, NY 14263, USA

\author{
A. Groman · L. Tian \\ Department of Biostatistics, Roswell Park Cancer Institute, \\ Elm and Carlton Streets, \\ Buffalo, NY 14263, USA \\ P. K. Singh · L. E. Sucheston \\ Department of Cancer Prevention and Control, Roswell Park \\ Cancer Institute, Elm and Carlton Streets, \\ Buffalo, NY 14263, USA
}

was less than $32 \mathrm{ng} / \mathrm{mL}$ in $65 \%$ of the 313 CRC patients. In the 50 patients receiving $\mathrm{D}_{3}$ supplementation, serum levels of $25(\mathrm{OH}) \mathrm{D}_{3}$ increased $(p=0.008)$, PTH decreased $(p=$ $0.036)$ and $24,25(\mathrm{OH})_{2} \mathrm{D}_{3}, 1,25(\mathrm{OH})_{2} \mathrm{D}_{3}$, VDBP levels and PBMC 24-OHase activity were unchanged. GC SNP rs222016 was associated with high $25(\mathrm{OH}) \mathrm{D}_{3}$ and 1,25 $(\mathrm{OH})_{2} \mathrm{D}_{3}$ levels at baseline while rs4588 and rs2282679 were associated with lower $25(\mathrm{OH}) \mathrm{D}_{3}$ and $1,25(\mathrm{OH})_{2} \mathrm{D}_{3}$ levels both before and after $\mathrm{D}_{3}$ supplementation. CYP2R1 rs12794714 and rs10500804 SNPs were significantly associated with low $25(\mathrm{OH}) \mathrm{D}_{3}$ levels after supplementation but not with baseline $25(\mathrm{OH}) \mathrm{D}_{3}$. Our results show that $\mathrm{D}_{3}$ supplementation increased $25(\mathrm{OH}) \mathrm{D}_{3}$ levels in all patients. $G C$ rs4588 and rs2283679 SNPs were associated with increased risk of vitamin $\mathrm{D}_{3}$ insufficiency and suboptimal increase in $25(\mathrm{OH}) \mathrm{D}_{3}$ levels after $\mathrm{D}_{3}$ supplementation. Individuals with these genotypes may require higher $\mathrm{D}_{3}$ supplementation doses to achieve vitamin $\mathrm{D}_{3}$ sufficiency.

\section{Introduction}

Serum $25(\mathrm{OH}) \mathrm{D}_{3}$ level is the accepted indicator of vitamin $\mathrm{D}_{3}$ sufficiency in humans. Since dietary sources of vitamin $\mathrm{D}_{3}$ are limited, the major cause of human vitamin $\mathrm{D}_{3}$ insufficiency (defined as serum $25(\mathrm{OH}) \mathrm{D}_{3}<32 \mathrm{ng} / \mathrm{mL}$ ) is inadequate exposure to the sun $[1,2]$. Several factors including living at higher latitudes, cultural practices limiting skin exposure to sunlight, advanced age, obesity, and dark skin pigmentation are associated with low serum $25(\mathrm{OH}) \mathrm{D}_{3}$ levels [3-5]. We have reported that recent cancer chemotherapy may be a predisposing factor for vitamin $\mathrm{D}_{3}$ deficiency in CRC patients [6]. 
The clinical significance of vitamin D insufficiency in patients with established colorectal cancer, especially those with metastatic disease, is unclear. However, the association between vitamin $\mathrm{D}_{3}$ insufficiency and an increased risk of developing colorectal cancer is supported by several case-control studies [7, 8]. In a Norwegian study, higher colorectal cancer mortality was observed when the diagnosis of colon cancer was made during winter or spring (lower $25(\mathrm{OH}) \mathrm{D}_{3}$ ) compared to summer and autumn (higher $25(\mathrm{OH}) \mathrm{D}_{3}$ ) [9]. Furthermore, the Nurse's Health Study (NHS) and Health Professionals follow-up study showed that the lowest risk of death (adjusted for other variables) from CRC disease was seen in patients in the highest quartile of serum $25(\mathrm{OH}) \mathrm{D}_{3}$ levels [10].

Polymorphisms in several vitamin D genes $(C Y P 2 R 1$, CYP27A1, CYP27B1, CYP24A1, VDBP and VDR) have been associated several human diseases, including CRC [11]. The proteins encoded by these genes include CYP2R1 and CYP27A1 which convert vitamin $\mathrm{D}$ to $25(\mathrm{OH}) \mathrm{D}_{3} .25(\mathrm{OH})$ $\mathrm{D}_{3}$ is then converted by CYP27B1 to $1,25(\mathrm{OH})_{2} \mathrm{D}_{3}$, the biologically most active form of vitamin $\mathrm{D}_{3}$. CYP24A1 converts $25(\mathrm{OH}) \mathrm{D}_{3}$ and $1,25(\mathrm{OH})_{2} \mathrm{D}_{3}$ to $24,25(\mathrm{OH})_{2} \mathrm{D}_{3}$ and $1,24,25$ $(\mathrm{OH})_{2} \mathrm{D}_{3}$, respectively, which are less active. Vitamin $\mathrm{D}$ binding protein (VDBP), encoded by $G C$ (group-specific component), is the transporter of vitamin $\mathrm{D}_{3}$ metabolites in circulation while VDR, a nuclear hormone receptor, mediates the action of vitamin $\mathrm{D}_{3}$ by transcriptionally controlling the expression of hormone sensitive genes. Studies show significant association between single nucleotide polymorphisms (SNP) in the GC (rs2282679), DHCR7 (rs12785878), and CYP2R1 (rs10741657) genes and serum $25(\mathrm{OH}) \mathrm{D}_{3}$ levels $[12,13]$. There are reported associations between $25(\mathrm{OH}) \mathrm{D}_{3}$ levels and SNPs in $G C$ (rs4588 and rs7041), VDR (rs10735810) and CYP27B1 (rs10877012) genes [14, 15]. The AA genotype of $V D R$ rs1544410 has been associated with higher serum $1,25(\mathrm{OH})_{2} \mathrm{D}_{3}$ levels compared to the $\mathrm{GG}$ genotype [16]. Reports on the effect of $\mathrm{D}_{3}$ supplementation on the associations between polymorphisms in the vitamin $\mathrm{D}_{3}$ pathway genes and serum $25(\mathrm{OH}) \mathrm{D}_{3}, 24,25(\mathrm{OH})_{2} \mathrm{D}_{3}$ and 1,25 $(\mathrm{OH})_{2} \mathrm{D}_{3}$ levels are few. A suboptimal response to $\mathrm{D}_{3}$ supplementation was associated with $G C$ rs4588 SNP in healthy adults [17]. Comprehensive studies to identify SNPs in the vitamin $\mathrm{D}_{3}$ metabolizing and signaling pathway genes that are associated with response to $\mathrm{D}_{3}$ supplementation will provide insight into factors influencing vitamin $\mathrm{D}$ health and information on the planning of prospective cancer chemoprevention and therapeutic clinical trials.

In this study, we measured serum vitamin $\mathrm{D}$ metabolite levels $\left(25(\mathrm{OH}) \mathrm{D}_{3}, 24,25(\mathrm{OH})_{2} \mathrm{D}_{3}, 1,25(\mathrm{OH})_{2} \mathrm{D}_{3}\right)$ together with vitamin $\mathrm{D}$ binding protein (VDBP) levels in 313 CRC patient samples and correlated these measures with SNPs in the major vitamin $\mathrm{D}_{3}$ metabolizing and signaling pathway genes at baseline and with vitamin D sufficiency. We also tested for associations between these SNPs and changes in the serum vitamin $\mathrm{D}_{3}$ metabolites levels in a subset of CRC patients receiving a fixed dose of 2,000 IU of oral cholecalciferol daily for 6 months.

\section{Materials and Methods}

Research Blood Sample Collections and Storage

Archived blood samples of 263 CRC patients were obtained from Roswell Park Cancer Institute (RPCI) Data Bank and BioRepository. Blood samples were also collected prospectively from RPCI CRC patients enrolled in a study of fixed oral dose of $2000 \mathrm{IU}$ of cholecalciferol $\left(\mathrm{D}_{3}\right)$ once daily for 6 months. Eligibility criteria, baseline and follow-up clinical evaluation of the patients enrolled in the $\mathrm{D}_{3}$ supplementation protocol has been published [18]. Protocols for these studies were both approved by the RPCI Institutional Review Board (IRB) prior to starting these studies.

Serum samples for vitamin $\mathrm{D}_{3}$ metabolite and PTH level measurements were collected before treatment and on days $14,30,60,90$, and 180 of $\mathrm{D}_{3}$ supplementation and stored at $-80{ }^{\circ} \mathrm{C}$ until assayed. VDBP was measured in samples collected at baseline and on day 90 only. Baseline blood samples collected in EDTA tubes and stored at $-80{ }^{\circ} \mathrm{C}$ was used for DNA isolation. Serum samples for PTH assay were stored at $-80{ }^{\circ} \mathrm{C}$ and were assayed within 12 months of samples collection. PTH levels in archived serum samples were not measured.

\section{Analytical Assays}

Serum $25(\mathrm{OH}) \mathrm{D}_{3}, 24,25(\mathrm{OH})_{2} \mathrm{D}_{3}$, and $1,25(\mathrm{OH})_{2} \mathrm{D}_{3}$ Assays

A high-performance liquid chromatographic assay with tandem mass spectrometric detection (LC/MS/MS) was used to simultaneously measure $24,25(\mathrm{OH})_{2} \mathrm{D}_{3}$ and $25(\mathrm{OH}) \mathrm{D}_{3}$ in $0.25 \mathrm{~mL}$ of human serum sample. Stable-isotope labeled 25 -Hydroxyvitamin $\mathrm{D}_{3}-(26,26,27,27,27-d 6)$ was the internal standard $[19,20]$. Sample preparation for LC/MS/MS analysis included liquid-liquid extraction using methanol and chloroform $(1: 3 \mathrm{v} / \mathrm{v})$. The dried organic layer containing $24,25(\mathrm{OH})_{2} \mathrm{D}_{3}$ and $25(\mathrm{OH}) \mathrm{D}_{3}$ was reconstituted in $60 \mu \mathrm{L}$ of methanol $(\mathrm{MeOH}) /$ water $(60 / 40 \%)$ and $25 \mu \mathrm{L}$ volumes were injected and separated on reverse phase $\mathrm{dC}-18$ column (Waters Corp) using $\mathrm{MeOH} /$ water gradient (0 min $80 \%$ $\mathrm{MeOH}, 3 \min 99 \% \mathrm{MeOH}, 10 \min 99 \% \mathrm{MeOH}, 10.1 \mathrm{~min}$ $80 \% \mathrm{MeOH}, 15 \min 80 \% \mathrm{MeOH}$ at flow rate of $220 \mu \mathrm{L} / \mathrm{min}$ ). TSQ Quantum ULTRA mass spectrometer with positive atmospheric pressure chemical ionization (APCI) source was used to monitor $24,25(\mathrm{OH})_{2} \mathrm{D}_{3}$, $25(\mathrm{OH}) \mathrm{D}_{3}$ and the internal standard at transitions of $\mathrm{m} / \mathrm{z}$ $399>127,383>365$ and $389>371$ respectively. The assay 
lower limit of detection were $0.25 \mathrm{ng} / \mathrm{mL}$ for both $24,25(\mathrm{OH})_{2} \mathrm{D}_{3}$ and $25(\mathrm{OH}) \mathrm{D}_{3}$. Serum $25(\mathrm{OH}) \mathrm{D}_{3}$ levels measured by our LC/MS/MS method were 10-17 \% higher than the values obtained using DiaSorin 25-hydroxyvitamin D RIA kits. Serum $1,25(\mathrm{OH})_{2} \mathrm{D}_{3}$ levels were measured using DiaSorin RIA kits as previously described [21].

\section{Plasma PTH and VDBP Assays}

Serum PTH levels were measured using biologically intact hPTH 1-84 immunoradiometric Kits from DiaSorin (Stilwell, MN). Quantitative determination of total serum vitamin D binding proteins (VDBP) was performed using K2314 VDBP ELISA kits from ALPCO immunoassays (Salem, NH). Both assays were performed according to the instructions supplied with kits.

\section{4-Hydroxylase Activity Assay}

PBMC 24-OHase activity was assayed as previously described [22, 23]. The assay consisted of $2 \times 10^{6} \mathrm{PBMC}$ (as the 24-OHase enzyme source), and $0.5 \mu \mathrm{Ci}(110,000 \mathrm{dpm})$ $\left[{ }^{3} \mathrm{H}\right]-25(\mathrm{OH}) \mathrm{D}_{3}$ as the substrate; total assay volume was $0.5 \mathrm{ml}$ of buffer ( $0.19 \mathrm{M}$ sucrose, $25 \mathrm{mM}$ sodium succinate, $2 \mathrm{mM} \mathrm{MgCl}, 1 \mathrm{mM}$ EDTA and $20 \mathrm{mM}$ HEPES), $\mathrm{pH}$ 7.4. The reaction was initiated by the addition of substrate followed by $30 \mathrm{~min}$ incubation at $37{ }^{\circ} \mathrm{C}$. $\left[{ }^{3} \mathrm{H}\right]-25(\mathrm{OH}) \mathrm{D}_{3}$ oxidative metabolites were extracted by liquid-liquid partition, separated by HPLC and measured by liquid scintillation counting of collected HPLC fractions. Radioactivity in the fractions containing all 24-oxidative metabolites of $25(\mathrm{OH})$ $\mathrm{D}_{3}$ were pooled and 24-OHase activity, normalized for variations in extraction efficiency, was calculated using the radioactivity ratio of pooled 24-oxidative metabolites/total radioactivity recovered and expressed as femtomoles per hour per $\mathrm{mg}$ of protein.

\section{Genotyping Assays}

Genomic DNA was isolated from whole blood samples using Flexi Gene DNA kits (Qiagen Inc, Valencio, CA). The quality and quantity of DNA isolated was determined using both Nanodrop (Thermo Scientific, Waltham, MA) and PicoGreen (Molecular Probes Inc., Eugene, OR) methods.

TagSNPs in CYP2R1, CYP27A1, CYP27B1, CYP24A1, $V D R$ and $G C$ genes were selected from databases (NCBI; HapMap) and from CYP24A1 re-sequenced data generated in our laboratory from Caucasian DNA samples from the Coreil Cell Repository (unpublished). Briefly, SNP genotype datasets for Caucasians were loaded into the Haploview program (version 4.0) (Broad Institute, MIT and Harvard, Cambridge, MA, USA) and polymorphisms with frequencies greater than $5 \%$ were selected for haplotype analysis at an $r^{2}$ threshold of 0.8 . Haplotypes close to or greater than $2 \%$ were organized into single blocks from which haplotype tagSNPs were derived. The tagger software was also used to generate tagSNPs. Other websites used for tagSNPs selection included NIEHS (http://snpinfo.niehs.nih.gov/snptag.htm) and GVS (http://gvs.gs.washington.edu/GVS/). A total of 80 tagSNPs were genotyped using the Sequenom MassArray platform (Sequenon, San Diego, CA) in accordance with the manufacturer's instructions (http://www.sequenom.com/ seq-genotyping). Controls were included to ensure genotyping accuracy in addition to genotyping approximately $10 \%$ of the samples in duplicates.

\section{Data Analysis}

Patients with baseline serum $25(\mathrm{OH}) \mathrm{D}_{3}$ levels $<20 \mathrm{ng} / \mathrm{mL}$, $20-31.9 \mathrm{ng} / \mathrm{mL}$ and $\geq 32 \mathrm{ng} / \mathrm{mL}$ were considered to be vitamin $\mathrm{D}_{3}$ deficient, insufficient and sufficient, respectively. Free index (a measure of non-protein bound) $25(\mathrm{OH})$ $\mathrm{D}_{3}, 24,25(\mathrm{OH})_{2} \mathrm{D}_{3}$ and $1,25(\mathrm{OH})_{2} \mathrm{D}_{3}$ were calculated as a molar ratio of each vitamin $\mathrm{D}_{3}$ metabolite/VDBP. Frequencies and relative frequencies were computed for categorical variables and numeric variables were summarized using mean, standard deviation, standard error of mean, median and range as appropriate. Fisher's exact test was used to study the association between categorical variables and the Wilcoxon rank sum test was used to compare the groups' numeric variables.

The generalized linear models with corresponding link function and distribution of different response variables were used to investigate the association between study variables and a set of variables for multivariate analysis. $P<0.05$ nominal significance level was used in all testing. All statistical analyses were done using SAS (version 9.1).

Association analysis of serum vitamin $\mathrm{D}_{3}$ metabolite concentrations with SNPs were performed using generalized linear models. Logistic regression models were used to measure SNP association analyses with sufficiency status (insufficient/deficient vs. sufficient). For the $D_{3}$ supplementation population, vitamin $\mathrm{D}_{3}$ metabolite levels were $\log$ transformed and genotypes were coded as 0,1 , and 2 for homozygous major, heterozygous and homozygous minor genotypes, respectively. Due to small sample size of $\mathrm{D}_{3}$ supplementation group and rarity of minor genotypes, the minor and heterozygous genotypes were pooled and compared to major genotype (reference group) for all SNPS. Models were adjusted for age, sex, BMI, tumor stage, chemotherapy status and plasma VDBP levels. The $\beta$-coefficients from the linear models represent the quantitative change in plasma measures with the addition of the minor allele. The $\beta$ coefficients from the logistic regression models reflect the increase in 
odds of deficiency (or sufficiency) with each additional copy of the variant allele.

\section{Results}

Patient Characteristics, Baseline Serum Vitamin $\mathrm{D}_{3}$ Metabolite and VDBP Levels

Characteristics, including self-reported racial background, of all 313 CRC patients, stratified into three vitamin status categories (deficient, insufficient, and sufficient, based on baseline serum $25(\mathrm{OH}) \mathrm{D}_{3}$ levels $)$, are shown in Table 1; $69.1 \%$ of the vitamin $\mathrm{D}_{3}$ sufficient patients had blood samples collected in summer/fall compared to $52.2 \%$ and $39.8 \%$ for the insufficient and deficient patients, respectively. Neither BMI nor other patient demographic characteristics (gender, age, race, and tumor stage) showed significant association with vitamin $\mathrm{D}_{3}$ status. Serum $24,25(\mathrm{OH})_{2} \mathrm{D}_{3}$ levels were significantly associated with baseline serum $25(\mathrm{OH}) \mathrm{D}_{3}$ levels $(p<0.0001)$, whereas serum $1,25(\mathrm{OH})_{2} \mathrm{D}_{3}$ and VDBP levels were not.
Effect of $\mathrm{D}_{3}$ Supplementation on Serum Vitamin $\mathrm{D}_{3}$ Metabolites, PTH, VDBP Levels and PBMC 24-OHase Activity

Time course of the changes in serum $25(\mathrm{OH}) \mathrm{D}_{3}, 24,25$ $(\mathrm{OH})_{2} \mathrm{D}_{3}, 1,25(\mathrm{OH})_{2} \mathrm{D}_{3}, \mathrm{PTH}$ and VDBP levels and PBMC 24-OHase activity during $\mathrm{D}_{3}$ supplementation are shown in Fig. 1. The increase in $25(\mathrm{OH})_{2} \mathrm{D}_{3}$ attained equilibrium levels by day 90 ; the largest percentage increase in $25(\mathrm{OH}) \mathrm{D}_{3}$ levels was in the vitamin $\mathrm{D}_{3}$ deficient category (Fig. 1a). Similar increases in $24,25(\mathrm{OH})_{2} \mathrm{D}_{3}$ levels were observed (Fig. 1b). The $1,25(\mathrm{OH})_{2} \mathrm{D}_{3}$ levels also increased but remained within the physiologic range of $20-100 \mathrm{pg} / \mathrm{mL}$ (Fig. 1c). Serum 25 $(\mathrm{OH}) \mathrm{D}_{3}$ and $24,25(\mathrm{OH})_{2} \mathrm{D}_{3}$ levels at baseline and during $\mathrm{D}_{3}$ supplementation were linearly correlated (Fig. 1d). The correlation between $25(\mathrm{OH}) \mathrm{D}_{3}$ and $1,25(\mathrm{OH})_{2} \mathrm{D}_{3}$, and between $24,25(\mathrm{OH})_{2} \mathrm{D}_{3}$ and $1,25(\mathrm{OH})_{2} \mathrm{D}_{3}$ serum levels are shown in Fig. 1e and f, respectively.

A decrease in serum PTH levels was observed within 30 days of starting $\mathrm{D}_{3}$ supplementation and no further decrease in PTH levels was observed from day 60 onwards (Fig. 2a). No significant changes in PBMC 24-OHase activity and serum

Table 1 Demographic and serum vitamin $D_{3}$ variables in CRC patients stratified by baseline serum vitamin $D_{3}$ status

\begin{tabular}{|c|c|c|c|c|c|}
\hline \multirow[t]{2}{*}{ Characteristics/variables } & & \multicolumn{3}{|c|}{ Baseline vitamin $\mathrm{D}_{3}$ status* } & \multirow[t]{2}{*}{$p$ value } \\
\hline & & Deficient $(N=88)$ & Insufficient $(N=115)$ & Sufficient $(N=110)$ & \\
\hline \multirow{2}{*}{\multicolumn{2}{|c|}{$\begin{array}{l}\text { Age, years }<40 \\
40-49\end{array}$}} & 4 & 4 & 9 & \multirow[t]{5}{*}{0.44} \\
\hline & & 13 & 24 & 12 & \\
\hline \multicolumn{2}{|l|}{$50-59$} & 26 & 26 & 32 & \\
\hline \multicolumn{2}{|l|}{$60-69$} & 29 & 37 & 34 & \\
\hline \multicolumn{2}{|l|}{$\geq 70$} & 15 & 25 & 23 & \\
\hline \multirow[t]{2}{*}{ Gender } & $\mathrm{F}$ & $44(50 \%)$ & $48(41.7 \%)$ & $55(50 \%)$ & \multirow[t]{2}{*}{0.37} \\
\hline & M & $44(50 \%)$ & $67(58.3 \%)$ & $55(50 \%)$ & \\
\hline \multirow[t]{3}{*}{ Race } & White & $76(86.4 \%)$ & $101(87.8 \%)$ & $100(90.9 \%)$ & \multirow[t]{3}{*}{0.52} \\
\hline & Black & $8(9.1 \%)$ & $12(10.4 \%)$ & $6(5.5 \%)$ & \\
\hline & Others & $4(4.5 \%)$ & $2(1.7 \%)$ & $4(3.6 \%)$ & \\
\hline \multirow[t]{2}{*}{ Tumor stage } & Early (I/II) & $8(9.1 \%)$ & $18(15.8 \%)$ & $16(14.7 \%)$ & \multirow[t]{2}{*}{0.35} \\
\hline & Advanced (III/IV) & $80(90.9 \%)$ & $96(84.2 \%)$ & $93(85.3 \%)$ & \\
\hline \multirow[t]{2}{*}{ Sample collection season } & Summer-Fall & $35(39.8 \%)$ & $60(52.2 \%)$ & $76(69.1 \%)$ & \multirow[t]{2}{*}{0.004} \\
\hline & Winter-Spring & $53(60.2 \%)$ & $55(47.8 \%)$ & $34(30.9 \%)$ & \\
\hline \multirow[t]{3}{*}{ BMI $\left(\mathrm{kg} / \mathrm{m}^{2}\right)$} & $<25$ & $27(30.7 \%)$ & $23(21.3 \%)$ & $34(33.0 \%)$ & \multirow[t]{3}{*}{0.065} \\
\hline & $25-30$ & $25(28.4 \%)$ & $43(39.8 \%)$ & $42(40.8 \%)$ & \\
\hline & $>30$ & $36(40.9 \%)$ & $42(38.9 \%)$ & $27(26.2 \%)$ & \\
\hline \multicolumn{2}{|c|}{ Vitamin D binding protein (VDBP) $(\mu \mathrm{g} / \mathrm{mL})$} & $354.1 \pm 77.6$ & $357.8 \pm 75.0$ & $387.3 \pm 102.4$ & 0.079 \\
\hline \multirow[t]{3}{*}{$\mathrm{D}_{3}$ metabolites } & $25(\mathrm{OH}) \mathrm{D}_{3}(\mathrm{ng} / \mathrm{mL})$ & $14.4 \pm 4.0$ & $25.7 \pm 3.4$ & $38.8 \pm 5.9$ & Inference \\
\hline & $24,25(\mathrm{OH})_{2} \mathrm{D}_{3}(\mathrm{ng} / \mathrm{ml})$ & $0.4 \pm 0.3$ & $1.0 \pm 0.7$ & $2.2 \pm 2.1$ & $<0.0001$ \\
\hline & $1,25(\mathrm{OH})_{2} \mathrm{D}_{3}(\mathrm{pg} / \mathrm{mL})$ & $53.0 \pm 16.2$ & $53.5 .4 \pm 15.1$ & $54.2 \pm 15.4$ & 0.46 \\
\hline
\end{tabular}

For numerical variables statistics represented as mean $\pm \mathrm{SD}$

For categorical variables statistics represented as frequency (\% relative frequency)

*Definitions of vitamin $\mathrm{D}_{3}$ status categories are based on serum $25(\mathrm{OH}) \mathrm{D}_{3}$ levels

$<20 \mathrm{ng} / \mathrm{mL}=$ deficient, $20-31.9 \mathrm{ng} / \mathrm{mL}=$ insufficient and $\geq 32 \mathrm{ng} / \mathrm{mL}=$ sufficient 

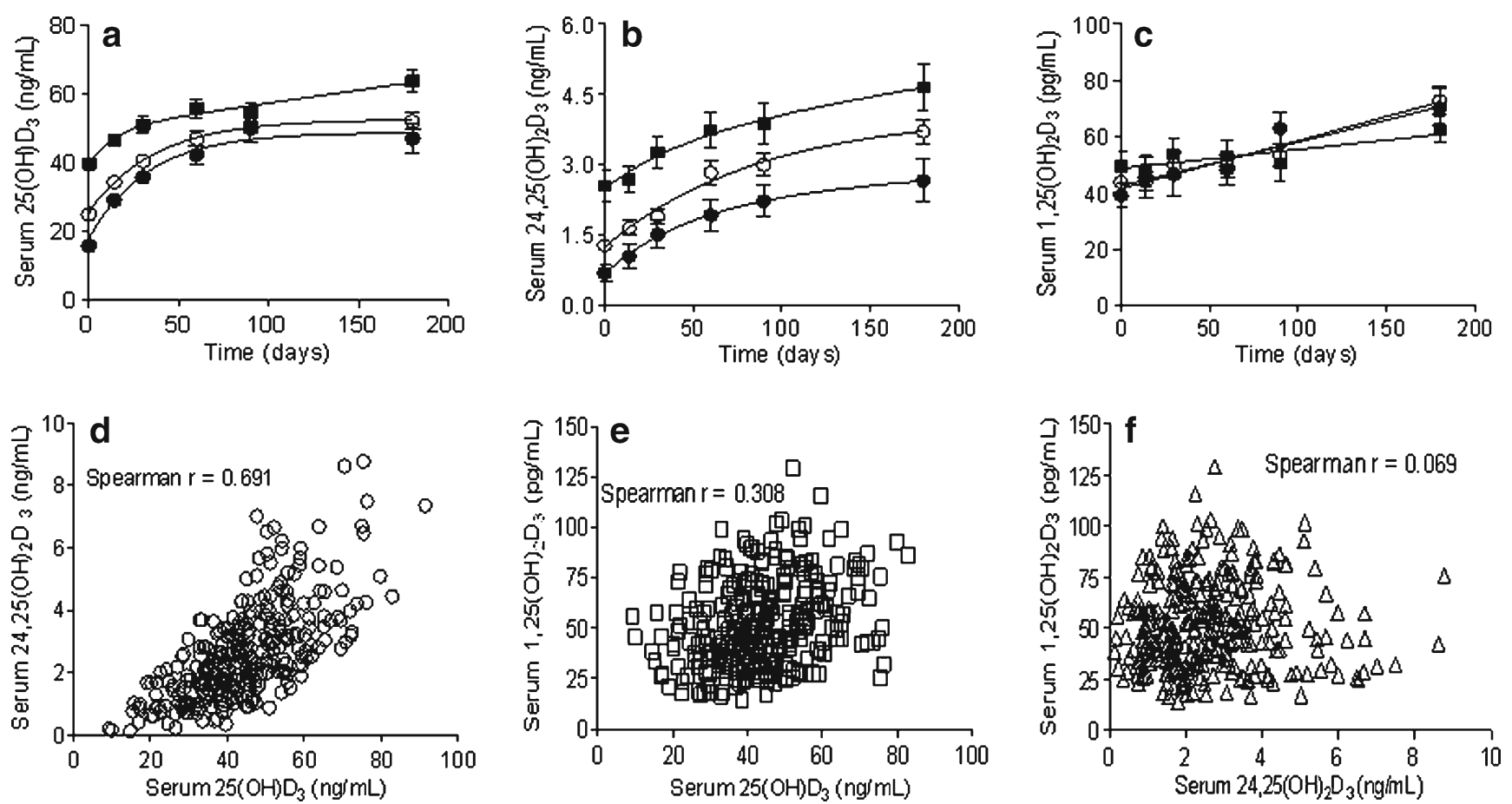

Fig. 1 Time course of the changes in serum $25(\mathrm{OH}) \mathrm{D}_{3}$ (panel a), $24,25(\mathrm{OH})_{2} \mathrm{D}_{3}$ (panel b), and $1,25(\mathrm{OH})_{2} \mathrm{D}_{3}$ (panel c) levels in vitamin $\mathrm{D}_{3}$ deficient (filled circle), insufficient (open circle), and sufficient (filled square) CRC patients receiving 2000IU of oral cholecalciferol daily. Vitamin $\mathrm{D}_{3}$ status stratification based on baseline serum $25(\mathrm{OH}) \mathrm{D}_{3}$ levels: deficient $<20 \mathrm{ng} / \mathrm{mL}(N=9)$, insufficient 20 to

$31.9 \mathrm{ng} / \mathrm{mL}(N=24)$ and sufficient $\geq 32 \mathrm{ng} / \mathrm{mL}(N=17)$. Panels d, e, and $\mathbf{f}$ show plots (and correlation coefficients) of serum $25(\mathrm{OH}) \mathrm{D}_{3}$ versus $24,25(\mathrm{OH})_{2} \mathrm{D}_{3}, 25(\mathrm{OH}) \mathrm{D}_{3}$ versus $1,25(\mathrm{OH}) \mathrm{D}_{3}$, and $24,25(\mathrm{OH})_{2} \mathrm{D}_{3}$ versus $1,25(\mathrm{OH}) \mathrm{D}_{3}$ levels at baseline and during $\mathrm{D}_{3}$ supplementation. Caption in panel $\mathbf{a}$, also refers to panels $\mathbf{b}$ and $\mathbf{c}$
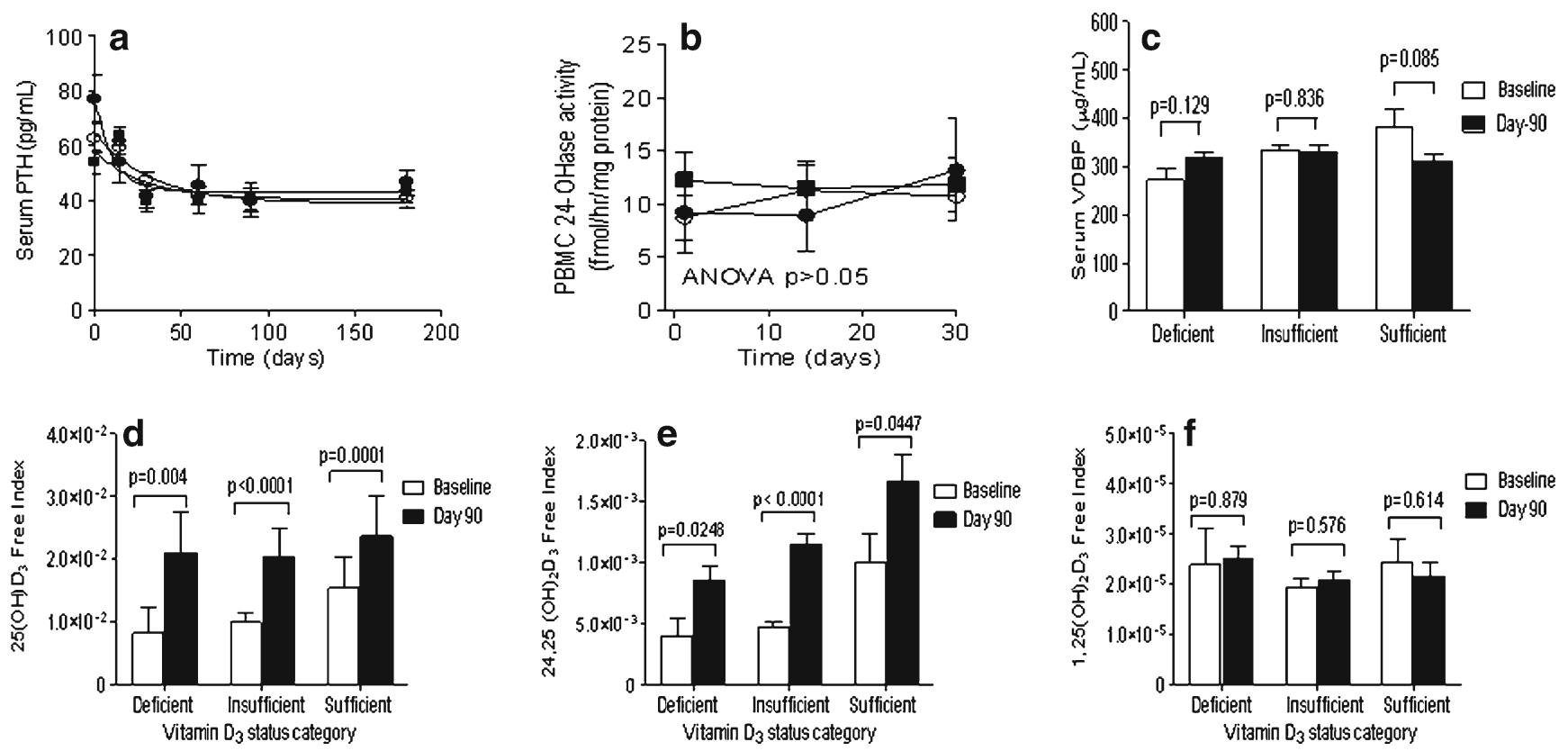

Fig. 2 Time course of the change in serum PTH levels (panel a) and PBMC 24-hydroxylase activity (panel b) in vitamin $\mathrm{D}_{3}$ deficiency (filled circle, $N=9$ ), insufficient (open circle, $N=24$ ), and sufficient (filled square, $N=17$ ) CRC patients receiving 2,000 IU of oral cholecalciferol daily; panel $\mathbf{c}$ shows the baseline and day 90 serum VDBP levels. Net effects of the cholecalciferol supplementation mediated changes in plasma vitamin $\mathrm{D}_{3}$ metabolite and VDBP levels were evaluated by calculating free index of $25(\mathrm{OH}) \mathrm{D}_{3}$ (panel d), $24,25(\mathrm{OH})_{2} \mathrm{D}_{3}$ (panel e) and $1,25(\mathrm{OH})_{2} \mathrm{D}_{3}$ (panel f) at baseline and on day 90 of the $\mathrm{D}_{3}$ supplementation. Free index $=$ molar ratio of vitamin $\mathrm{D}_{3}$ metabolite/VDBP 
VDBP levels were observed during $\mathrm{D}_{3}$ supplementation (Fig. $2 b$ and c). Baseline and day 90 serum VDBP levels for all three vitamin $\mathrm{D}_{3}$ status categories were within the normal range $(200-550 \mu \mathrm{g} / \mathrm{mL}) . \mathrm{D}_{3}$ supplementation increased the free indices of serum $25(\mathrm{OH}) \mathrm{D}_{3}$ and $24,25(\mathrm{OH})_{2} \mathrm{D}_{3}$ (Fig. $2 \mathrm{~d}$ and e); $1,25(\mathrm{OH})_{2} \mathrm{D}_{3}$ free index did not change (Fig. 2f).

In summary, the significant consequences of $\mathrm{D}_{3}$ supplementation were the decrease in serum PTH levels by day 30 , and increase in $25(\mathrm{OH}) \mathrm{D}_{3}$ levels on days 30 and 90 ; the changes in serum of $24,24(\mathrm{OH})_{2} \mathrm{D}_{3}, 1,25(\mathrm{OH})_{2} \mathrm{D}_{3}$ and VDBP levels and PBMC 24-OHase were not significant at any of the time points analyzed (Table 2).

Vitamin D SNPs and Serum Vitamin $\mathrm{D}_{3}$ Metabolite Levels and Risk of Vitamin $\mathrm{D}_{3}$ Insufficiency

Associations between the tag SNPs from the 6 genes ( $V D R$, GC, CYP2R1, CYP27A1, CYP27B1, and CYP24A1) with baseline serum levels of $25(\mathrm{OH}) \mathrm{D}_{3}, 24,25(\mathrm{OH})_{2} \mathrm{D}_{3}$, and $1,25(\mathrm{OH})_{2} \mathrm{D}_{3}$ were evaluated in the $313 \mathrm{CRC}$ patients. At $p<0.05$, two GC SNPs (rs4588 and rs2282679, in linkage disequilibrium [LD] with each other, $\left.r^{2}=0.98\right)$, two CYP24A1 SNPs (rs2762934 and rs2762939) and one VDR SNP (rs11168267) were associated with low baseline levels of at least one serum vitamin $\mathrm{D}_{3}$ metabolite; SNPs associated with high baseline levels of at least one serum vitamin $\mathrm{D}_{3}$ metabolite were $G C$ rs222016, CYP24A1 rs111675277 and VDR rs11574077 (Table 3). After multiple testing, only $G C$ rs4588 remained significantly associated with low baseline serum $1,25(\mathrm{OH})_{2} \mathrm{D}_{3}$ levels.
The $G C$ rs4588 and rs2282679 SNPs were associated with less increase in serum $25(\mathrm{OH}) \mathrm{D}_{3}$ and $1,25(\mathrm{OH})_{2} \mathrm{D}_{3}$ levels after 90 days of $\mathrm{D}_{3}$ supplementation in 50 patients (Table 3 ). Six other SNPs, rs10500804 and rs12794714 (CYP2R1), rs6022999 (CYP24A1) and rs2525044, rs739837, rs7975232 $(V D R)$ were also associated with low levels of at least one vitamin D metabolite after supplementation (Table 3). Only two SNPs were associated with higher serum vitamin $\mathrm{D}_{3}$ metabolite levels after supplementation (Table 3).

The risk of vitamin D insufficiency in association with tagSNPs was evaluated in the 313 CRC patients stratified into 2 groups: vitamin $\mathrm{D}_{3}$ sufficient (reference, baseline serum $\left.25(\mathrm{OH}) \mathrm{D}_{3} \geq 32 \mathrm{ng} / \mathrm{ml}\right)$ and vitamin $\mathrm{D}_{3}$ insufficient (baseline serum $25(\mathrm{OH}) \mathrm{D}_{3}<32 \mathrm{ng} / \mathrm{mL}$ ). $G C$ rs 4588 and rs2282679 were associated with increased odds of vitamin $\mathrm{D}_{3}$ insufficiency while $G C$ rs222014 and CYP24A1 rs4809958 and rs6013905 in LD (with $r^{2}=1$ ) were associated with reduced odds of insufficiency (Table 4).

\section{Discussion}

In this study, $64.9 \%$ of CRC patients had baseline serum $25(\mathrm{OH}) \mathrm{D}_{3}$ levels less than $32 \mathrm{ng} / \mathrm{mL}$. Similar high percentage of vitamin $\mathrm{D}_{3}$ deficient and insufficient individuals have been reported in healthy controls and patients with acute myeloid leukemia, colorectal, prostate, and breast cancer in Western New York [24-26]. Therefore, the high prevalence of vitamin $\mathrm{D}_{3}$ deficiency in these CRC patients simply reflects the vitamin $D_{3}$ status of the general population in

Table 2 Changes in vitamin $D_{3}$ metabolites and other vitamin $D_{3}$ related variables measured during $D_{3}$ supplementation in 50 CRC patients categorized by vitamin $\mathrm{D}_{3}$ status

\begin{tabular}{|c|c|c|c|c|c|}
\hline \multirow[t]{2}{*}{ Time (days) } & \multirow{2}{*}{$\begin{array}{l}\text { Changes in serum } \mathrm{D}_{3} \\
\text { variables from baseline }\end{array}$} & \multicolumn{3}{|l|}{ Vitamin $\mathrm{D}_{3}$ status } & \multirow[t]{2}{*}{$p$ value } \\
\hline & & Deficient $(N=9)$ & Insufficient $(N=24)$ & Sufficient $(N=17)$ & \\
\hline \multirow[t]{5}{*}{30} & $\Delta 25(\mathrm{OH}) \mathrm{D}_{3}$ & $20.6 \pm 5.9$ & $15.5 \pm 7.8$ & $11.0 \pm 9.6$ & 0.009 \\
\hline & $\Delta 24,25(\mathrm{OH})_{2} \mathrm{D}_{3}$ & $0.8 \pm 0.6$ & $0.6 \pm 0.6$ & $0.7 \pm 1.2$ & 0.80 \\
\hline & $\Delta 1,25(\mathrm{OH})_{2} \mathrm{D}_{3}$ & $7.5 \pm 20.5$ & $6.5 \pm 15.1$ & $4.4 \pm 18.7$ & 0.9 \\
\hline & $\triangle \mathrm{PTH}$ & $-35.5 \pm 18.2$ & $-15.4 \pm 25.0$ & $-16.3 \pm 19.9$ & 0.04 \\
\hline & $\triangle \mathrm{PBMC} C \mathrm{CY} 24 \mathrm{~A} 1$ activity & $3.5 \pm 10.1$ & $2.0 \pm 6.0$ & $-0.3 \pm 8.4$ & 0.70 \\
\hline \multirow[t]{5}{*}{90} & $\Delta 25(\mathrm{OH}) \mathrm{D}_{3}$ & $34.5 \pm 11.1$ & $26.3 \pm 11.6$ & $13.8 \pm 11.3$ & 0.0007 \\
\hline & $\Delta 24,25(\mathrm{OH})_{2} \mathrm{D}_{3}$ & $1.5 \pm 1.0$ & $1.7 \pm 1.0$ & $1.3 \pm 1.7$ & 0.30 \\
\hline & $\Delta 1,25(\mathrm{OH})_{2} \mathrm{D}_{3}$ & $23.7 \pm 20.9$ & $9.4 \pm 20.5$ & $1.0 \pm 23.1$ & 0.10 \\
\hline & $\triangle \mathrm{PTH}$ & $-32.0 \pm 14.0$ & $-21.6 \pm 29.4$ & $-15.1 \pm 23.4$ & 0.20 \\
\hline & $\triangle \mathrm{VDBP}$ & $44.4 \pm 71.2$ & $-3.4 \pm 61.8$ & $-69.3 \pm 166.1$ & 0.09 \\
\hline \multirow[t]{4}{*}{180} & $\Delta 25(\mathrm{OH}) \mathrm{D}_{3}$ & $32.5 \pm 14.6$ & $27.5 \pm 12.0$ & $21.7 \pm 15.4$ & 0.20 \\
\hline & $\Delta 24,25(\mathrm{OH})_{2} \mathrm{D}_{3}$ & $2.0 \pm 1.3$ & $2.3 \pm 1.2$ & $2.1 \pm 2.0$ & 0.60 \\
\hline & $\Delta 1,25(\mathrm{OH})_{2} \mathrm{D}_{3}$ & $31.1 \pm 19.6$ & $29.3 \pm 27.4$ & $12.0 \pm 27.0$ & 0.10 \\
\hline & $\triangle \mathrm{PTH}$ & $-30.3 \pm 23.4$ & $-24.1 \pm 24.4$ & $-13.3 \pm 21.7$ & 0.20 \\
\hline
\end{tabular}

Statistics represent mean \pm SD. Tests for equality for all the variables between baseline $25(\mathrm{OH}) \mathrm{D}_{3}$ groups at baseline, day 30,90 and 180 done by Chi-square tests 
Table 3 Associations between SNPs in the vitamin $\mathrm{D}_{3}$ pathway genes with serum $25(\mathrm{OH}) \mathrm{D}_{3}, 24,25(\mathrm{OH})_{2} \mathrm{D}_{3}$ and $1,25(\mathrm{OH})_{2} \mathrm{D}_{3}$ levels at baseline and after 90 -days of $\mathrm{D}_{3}$ supplementation

\begin{tabular}{|c|c|c|c|c|c|c|c|}
\hline \multirow[t]{2}{*}{$\mathrm{D}_{3}$ metabolites } & \multirow[t]{2}{*}{ Gene } & \multirow[t]{2}{*}{ SNP ID } & \multirow[t]{2}{*}{ Function } & \multicolumn{2}{|c|}{ Baseline $(N=313)$} & \multicolumn{2}{|c|}{ After $\mathrm{D}_{3}$ supplementation $(N=50)^{\mathrm{a}}$} \\
\hline & & & & $\beta$ & $p$ value $^{\mathrm{b}}$ & $\beta$ & $p$ value $\mathrm{e}^{\mathrm{b}}$ \\
\hline \multirow[t]{8}{*}{$25(\mathrm{OH}) \mathrm{D}_{3}$} & \multirow[t]{3}{*}{$G C(V D B P)$} & rs 4588 & Exon/Missense & -2.43 & 0.017 & -0.19 & 0.0009 \\
\hline & & rs2282679 & Intron & -2.49 & 0.015 & -0.19 & 0.0008 \\
\hline & & rs222016 & Intron & 2.24 & 0.035 & \multicolumn{2}{|l|}{ Not significant } \\
\hline & \multirow[t]{3}{*}{$C Y P 2 R I$} & rs 10500804 & Intron & \multirow{3}{*}{\multicolumn{2}{|c|}{ Not significant }} & -0.13 & 0.04 \\
\hline & & rs12794714 & Exon/Synonymous & & & -0.13 & 0.04 \\
\hline & & rs7129781 & Intron & & & 0.23 & 0.04 \\
\hline & $C Y P 24 A 1$ & rs111675277 & Intron & 5.15 & 0.028 & Not significant & \\
\hline & $V D R$ & rs11168267 & Intron & -3.59 & 0.030 & & \\
\hline \multirow[t]{3}{*}{$24,25(\mathrm{OH})_{2} \mathrm{D}_{3}$} & $C Y P 2 R 1$ & rs7129781 & Intron & \multirow{2}{*}{\multicolumn{2}{|c|}{ Not significant }} & 0.53 & 0.02 \\
\hline & CYP24A1 & rs6022999 & Intron & & & -0.32 & 0.02 \\
\hline & $V D R$ & rs 11574077 & Intron & 0.71 & 0.023 & Not significant & \\
\hline \multirow[t]{9}{*}{$1,25(\mathrm{OH})_{2} \mathrm{D}_{3}$} & $G C(V D B P)$ & rs 4588 & Exon/Missense & -4.86 & $0.0008^{\mathrm{c}}$ & -0.28 & 0.01 \\
\hline & & rs2282679 & Intron & -4.69 & 0.0012 & -0.27 & 0.02 \\
\hline & & rs222016 & Intron & 3.40 & 0.025 & \multirow[t]{3}{*}{ Not significant } & \\
\hline & $C Y P 24 A 1$ & rs2762934 & mRNA-untranslated & -4.01 & 0.010 & & \\
\hline & & rs2762939 & Intron & -3.72 & 0.007 & & \\
\hline & $V D R$ & rs2525044 & Intron & \multirow{4}{*}{\multicolumn{2}{|c|}{ Not significant }} & -0.34 & 0.007 \\
\hline & & rs 11574077 & Intron & & & 0.59 & 0.01 \\
\hline & & rs739837 & mRNA-untranslated & & & -0.42 & 0.002 \\
\hline & & rs7975232 & Intron & & & -0.43 & 0.001 \\
\hline
\end{tabular}

Only significant association $(p<0.05)$ between SNPs and either baseline or day-90 plasma vitamin $\mathrm{D}_{3}$ variables are shown. The only baseline and day-90 overlapping associations were between $G C$ (rs 4855 and rs2282679) with both $25(\mathrm{OH}) \mathrm{D}_{3}$ and $1,25(\mathrm{OH})_{2} \mathrm{D}_{3}$. SNPs in linkage disequilibrium [LD]: rs4855/rs2282679 $\left(\mathrm{r}^{2}=0.98\right), \mathrm{rs} 10500804 / \mathrm{rs} 12794714\left(\mathrm{r}^{2}=1.0\right)$ and $\mathrm{rs} 7975232 / \mathrm{rs} 739837\left(r^{2}=0.9\right)$. CYP2R1 rs7129781 was associated with high $25(\mathrm{OH}) \mathrm{D}_{3}$ and $24,25(\mathrm{OH})_{2} \mathrm{D}_{3}$ levels after $\mathrm{D}_{3}$ supplementation while $V D R$ rs 11574077 was associated with high $1,25(\mathrm{OH})_{2} \mathrm{D}_{3}$ levels

${ }^{a}$ Most frequent genotype was used as reference and compared with pooled heterozygous and rare genotypes because of small sample size

${ }^{\mathrm{b}}$ Raw $p$ values (not corrected for multiple testing)

${ }^{\mathrm{c}}$ The only significant association after multiple testing

Western New York. As expected, $25(\mathrm{OH}) \mathrm{D}_{3}$ levels were higher in blood samples collected in summer/fall than in samples collected in winter/spring. There was no association

Table 4 Genotype association with vitamin $\mathrm{D}_{3}$ status at baseline

\begin{tabular}{llll}
\hline Gene & SNPs ID & OR $(95 \% \mathrm{CI})$ & $p$ value \\
\hline$G C$ & rs222014 & $0.476(0.27-0.84)$ & 0.009 \\
$C Y P 24 A 1$ & rs4809958 & $0.570(0.35-0.92)$ & 0.021 \\
$C Y P 24 A 1$ & rs6013905 & $0.580(0.36-0.93)$ & 0.021 \\
$G C$ & rs4588, & $1.65(1.07-2.58)$ & 0.026 \\
$G C$ & rs2282679 & $1.65(1.07-2.58)$ & 0.026 \\
\hline
\end{tabular}

$25(\mathrm{OH}) \mathrm{D}_{3}$ reference group is sufficient (coded as zero), $1=$ deficient + insufficient; increase in odds of deficient/insufficient for each additional copy of variant allele

${ }^{\text {a }}$ SNPs in linkage disequilibrium [LD] with each other

${ }^{\mathrm{b}}$ SNPs in linkage disequilibrium [LD] with each other

${ }^{\mathrm{c}}$ This SNP is located in an exon, all others are in introns between $25(\mathrm{OH}) \mathrm{D}_{3}$ levels and race perhaps because of the small sample size of Black Americans in this study.

The increase in $25(\mathrm{OH}) \mathrm{D}_{3}$ and decrease in PTH levels which we observed in all vitamin $\mathrm{D}_{3}$ status categories, is consistent with prior reports and were expected as physiologic response to $\mathrm{D}_{3}$ supplementation. However, other reports indicate that $\mathrm{D}_{3}$ supplementation has no effect on serum PTH levels $[27,28]$. These contradictory observations may reflect differences in $\mathrm{D}_{3}$ supplementation doses utilized, calcium homeostasis related to dietary calcium intake and other calciotropic hormones. Our data suggest that serum $24,25(\mathrm{OH})_{2} \mathrm{D}_{3}, 1,25$ $(\mathrm{OH})_{2} \mathrm{D}_{3}$, and VDBP levels are of limited value as measures of response to $\mathrm{D}_{3}$ supplementation. Changes in serum $25(\mathrm{OH}) \mathrm{D}_{3}$ without associated change in serum $1,25(\mathrm{OH})_{2} \mathrm{D}_{3}$ levels during $\mathrm{D}_{3}$ supplements has been reported [29]. Moreover, there is no difference in baseline serum $24,25(\mathrm{OH})_{2} \mathrm{D}_{3}$ levels in these CRC patients $(1.4 \pm 0.5 \mathrm{ng} / \mathrm{mL})$ and that reported in healthy controls $[30,31]$. This finding suggests that $25(\mathrm{OH}) \mathrm{D}_{3}-24-$ hydroxylation may not play a critical role in the pathogenesis 
of systemic vitamin $\mathrm{D}_{3}$ insufficiency in CRC patients. The use of serum $24,25(\mathrm{OH})_{2} \mathrm{D}_{3}$ levels in evaluating the role of $24-$ hydroxylase in vitamin $\mathrm{D}_{3}$ status and responses to cholecalciferol supplementation is, however, of limited value because of its further metabolism, by the same enzyme, to $25(\mathrm{OH}) \mathrm{D}_{3}$ 23,26-lactone and cholecalcoic acid. Whereas, the decrease in $25(\mathrm{OH}) \mathrm{D}_{3}$ is not a useful measure of 24-hydroxylase because it is also a substrate of non 24-hydroxylase enzymes such as CYP11A1 [32, 33].

We found two major kinetic differences between the changes in total and free serum $25(\mathrm{OH}) \mathrm{D}_{3}, 24,25(\mathrm{OH})_{2} \mathrm{D}_{3}$, and $1,25(\mathrm{OH})_{2} \mathrm{D}_{3}$ levels during $\mathrm{D}_{3}$ supplementation: First, while the increase in total serum $25(\mathrm{OH}) \mathrm{D}_{3}$ and 24,25 $(\mathrm{OH})_{2} \mathrm{D}_{3}$ levels was biphasic, the increase in total serum $1,25(\mathrm{OH})_{2} \mathrm{D}_{3}$ levels was linear. Second, free indices of both $25(\mathrm{OH}) \mathrm{D}_{3}$ and $24,25(\mathrm{OH})_{2} \mathrm{D}_{3}$ increased whereas 1,25 $(\mathrm{OH})_{2} \mathrm{D}_{3}$ free index did not change. These observations suggest that changes in total and free serum $1,25(\mathrm{OH})_{2} \mathrm{D}_{3}$ levels were insufficient to trigger changes in PBMC 24-OHase and serum calcium levels. Free $1,25(\mathrm{OH})_{2} \mathrm{D}_{3}$ index is the serum measure highly correlated with hypercalcemia [34]. Although underlying mechanisms of the kinetic differences in $25(\mathrm{OH})$ $\mathrm{D}_{3}$ and $1,25(\mathrm{OH})_{2} \mathrm{D}_{3}$ changes during $\mathrm{D}_{3}$ supplementation are unknown, we suggest tight reciprocal regulation of 1,25 $(\mathrm{OH})_{2} \mathrm{D}_{3}$ levels by CYP24A1 and CYP27B1 catalyzed metabolism prevents the increase serum $1,25(\mathrm{OH})_{2} \mathrm{D}_{3}$ levels. Differences in the VDBP capacity and binding affinity along with variations in adipose tissue storage may play a further role in regulating serum $1,25(\mathrm{OH})_{2} \mathrm{D}_{3}$ levels. The percentages of free forms of $25(\mathrm{OH}) \mathrm{D}_{3}$ and $1,25(\mathrm{OH})_{2} \mathrm{D}_{3}$ in circulation are $0.04 \%$ and $0.4 \%$, respectively while VDBP affinity for 25 $(\mathrm{OH}) \mathrm{D}_{3}$ is $5 \times 10^{-8}-9.5 \times 10^{-11} \mathrm{M}$ compared to $\sim 4 \times 10^{-7} \mathrm{M}$ for $1,25(\mathrm{OH})_{2} \mathrm{D}_{3}[35,36]$.

Our results show that genetic variants of $G C$ SNPs rs 4588 and rs2282679 were associated with low baseline levels of 25 $(\mathrm{OH}) \mathrm{D}_{3}$ and $1,25(\mathrm{OH})_{2} \mathrm{D}_{3}$, with increased odds of vitamin $\mathrm{D}_{3}$ insufficiency and with suboptimal response to $\mathrm{D}_{3}$ supplementation in CRC patients. These findings are consistent with previous reports where these same SNPs have been associated with low serum $25(\mathrm{OH}) \mathrm{D}_{3}$ in both healthy and patients with a variety of diseases including cancer [7-11] and reduced serum $25(\mathrm{OH}) \mathrm{D}_{3}$ changes after vitamin $\mathrm{D}_{3}$ supplementation in healthy volunteers [12]. Although, genome wide studies have associated CYP2R1 SNPs rs10500804 and rs12794714, with vitamin D levels and vitamin D insufficiency $[7,8]$ the present study only showed an association after supplementation.

GC SNP rs222014 and CYP24A1 SNPs rs4809958 and rs6013905 were associated with reduced risk of vitamin $\mathrm{D}_{3}$ insufficiency, while $G C$ SNPs rs4588 and rs2282679 were associated with increased risk of insufficiency. However, it is unclear why GC rs222016 and CYP24A1 rs111675277, SNPs associated with high $25(\mathrm{OH}) \mathrm{D}_{3}$ levels, were not associated with reduced risk of $\mathrm{D}_{3}$ insufficiency. Possible explanations may include differences in statistical analysis (continuous vs. categorical OR), the character of the colorectal cancer disease itself and/or small sample size. Thus $G C$ rs222014 and CYP24A1 rs4809958 and rs6013905 SNPs could be potential predictive markers for low risk vitamin $\mathrm{D}_{3}$ insufficiency, while $G C$ rs 4588 and rs 2282679 may be both predictive of insufficiency and reduced response to $\mathrm{D}_{3}$ supplementation in CRC patients.

In summary, we found that baseline serum $25(\mathrm{OH}) \mathrm{D}_{3}$ levels and polymorphisms in the vitamin $\mathrm{D}_{3}$ pathway genes, especially in the $G C$ and $C Y P 24 A 1$ genes affect response to $\mathrm{D}_{3}$ supplementation in CRC patients and are associated with increased risk of vitamin $\mathrm{D}_{3}$ insufficiency. Further studies, in large populations, are needed to confirm and determine if individuals with $G C$ rs 4588 or rs 2282679 SNPs require higher doses of $D_{3}$ supplementation to achieve vitamin $D_{3}$ sufficiency.

Acknowledgments We thank Dr. G.S. Reddy (Epimer LLC and Department of Chemistry, Brown University, Providence, RI, USA), and Dr. M. Uskokovic (Hoffmann LaRoche Inc. Nutley, NJ, USA) for supplying analytical grade authentic vitamin $\mathrm{D}_{3}$ oxidative metabolites for the LC/MS/MS assays. We are grateful to the following RPCI CSCG Shared Resources, Data Bank and BioRepository, Pharmacokinetics/ Pharmacodynamic, Clinical Research Services and the Genomics Shared Resources for facilitating the collection and analytical aspects the study samples. We thank Ms. Jeanne McMahon and Michelle Panasiewicz for their excellent and tireless help in coordinating the clinical aspects of study and sample collection and processing, respectively.

Financial Support This study was supported by NIH/NCI grant R21 CA-141187 and RPCI Alliance Foundation (JRM), ACS Grant MRSG-04-270-01 and Lisa Legacy Foundation (MGF) and NCI grant P30 CA47904.

Conflict of interest The authors declare that they have no conflict of interest

Open Access This article is distributed under the terms of the Creative Commons Attribution License which permits any use, distribution, and reproduction in any medium, provided the original author(s) and the source are credited.

\section{References}

1. Holick MF (2004) Sunlight and vitamin D for bone health and prevention of autoimmune diseases, cancer and cardiovascular diseases. Am J Clin Nutr 80:1678S-1688S

2. Hollis BW (2005) Circulating 25-hydroxyvitamin D levels indicative of vitamin D sufficiency: Implications for establishing a new effective dietary intake recommendation for vitamin D. J Nutr 135:317-322

3. Goldner WS, Stoner JA, Thompson J, Taylor K, Larson L, Erickson J, McBride C (2008) Prevalence of vitamin D insufficiency and deficiency in morbidly obese patients: a comparison with non-obese controls. Obes Surg 18:145-150

4. Linnebur SA, Vondracek SF, Vande Griend JP, Ruscin JM, McDermott MT (2007) Prevalence of vitamin D insufficiency in elderly ambulatory outpatients in Denver, Colorado. Am J Geriatr Pharmacother 5:1-8 
5. Chen TC, Chimeh F, Lu Z, Mathieu J, Person KS, Zhang A, Kohn N, Martinello S, Berkowitz R, Holick MF (2007) Factors that influence the cutaneous synthesis and dietary sources of vitamin D. Arch Biochem Biophys 460:213-217

6. Fakih MG, Trump DL, Johnson CS, Tian L, Muindi J, Sunga AY (2009) Chemotherapy is linked to severe vitamin D deficiency in patients with colorectal cancer. Int J Color Dis 24:219-224

7. Tangrea J, Helzlsouer K, Pietinen P, Taylor P, Hollis B, Virtamo J, Albanes D (1997) Serum levels of vitamin D metabolites and the subsequent risk of colon and rectal cancer in Finnish men. Cancer Causes Control 8:615-625

8. Wu K, Feskanich D, Fuchs CS, Willett WC, Hollis BW, Giovannucci E (2007) A nested case control study of plasma 25hydroxyvitamin D concentrations and risk of colorectal cancer. J Natl Cancer Inst 99:1120-1129

9. Moan J, Porojnicu A, Lagunova Z, Berg JP, Dahlback A (2007) Colon cancer: prognosis for different latitudes, age groups and seasons in Norway. J Photochem Photobiol 89:148-155

10. Ng K, Meyerhardt JA, Wu K, Feskanich D, Hollis BW, Giovannucci EL, Fuchs CS (2008) Circulating 25 hydroxyvitamin D levels and survival in patients with colorectal cancer. J Clin Oncol 26:2984-2991

11. Dong LM, Ulrich CM, Hsu L, Duggan DJ, Benitez DS, White E, Slattery ML, Farin FM, Makar KW, Carlson CS, Caan BJ, Potter JD, Peters U (2009) Vitamin D related genes, CYP24A1 and CYP27B1, and colon cancer risk. Cancer Epidemiol Biomarkers Prev 18:2540-2548

12. Wang TJ, Wang TJ, Zhang F, Richards JB, Kestenbaum B, van Meurs JB, Berry D, Kiel DP, Streeten EA, Ohlsson C, Koller DL, Peltonen L, Cooper JD, O'Reilly PF, Houston DK, Glazer NL, Vandenput L, Peacock M, Shi J, Rivadeneira F, McCarthy MI, Anneli P, de Boer IH, Mangino M, Kato B, Smyth DJ, Booth SL, Jacques PF, Burke GL, Goodarzi M (2010) Common genetic determinants of D insufficient; a genome-wide association study. Lancet 376:180-188

13. Ahn J, Yu K, Stolzenberg-Solomon R, Simon KC, McCullough ML, Gallicchio L, Jacobs EJ, Ascherio A, Helzlsouer K, Jacobs KB, Li Q, Weinstein SJ, Purdue M, Virtamo J, Horst R, Wheeler W, Chanock S, Hunter DJ, Hayes RB, Kraft P, Albanes D (2010) Genome-wide association study of circulating vitamin D levels. Hum Mol Genet 19:2739-2745

14. McGrath JJ, Saha S, Burne TH, Eyles DW (2010) A systematic review of the association between common single nucleotide polymorphisms and 25-hydroxyvitamin D concentrations. J Steroid Biochem Mol Biol 121:471-477

15. Bu FX, Armas L, Lappe J, Zhou Y, Gao G, Wang HW, Recker R, Zhao LJ (2010) Comprehensive association analysis of nine candidate genes with serum 25 -hydroxy vitamin D levels among healthy Caucasian subjects. Hum Genet 128:549-556

16. Ma J, Stampfer MJ, Gann PH, Hough HL, Giovannucci E, Kelsey KT, Hennekens CH, Hunter DJ (1998) Vitamin D receptor polymorphisms, circulating vitamin D metabolites, and risk of prostate cancer in United States physicians. Cancer Epidemiol Biomarkers Prev 7:385-390

17. Fu L, Yun F, Oczak M, Wong BY, Vieth R, Cole DE (2009) Common genetic variants of the vitamin D binding protein (DBP) predict differences in response of serum 25-hydroxyvitamin D [25(OH)D] to vitamin D supplementation. Clin Biochem 42:1174-1177

18. Fakih MG, Andrews C, McMahon J, Muindi JR (2012) A prospective clinical trial of cholecalciferol $2000 \mathrm{IU} /$ day in colorectal cancer patients: evidence of a chemotherapy-response interaction. Anticancer Res 32:1333-1338

19. Chen H, Mccoy LF, Schleicher RL, Pfeiffer CM (2008) Measurement of 25-hydroxyvitamin $\mathrm{D}_{3}\left(25 \mathrm{OHD}_{3}\right)$ and 25hydroxyvitamin $\mathrm{D}_{2}\left(25 \mathrm{OHD}_{2}\right)$ in human serum using liquid chromatography-tandem mass spectrometry and its comparison to a radioimmunoassay method. Clinica Chimica Acta 391:6-12
20. Maunsell Z, Wright DJ, Rainbow SJ (2005) Routine isotopedilution liquid chromatography-tandem mass spectrometry assay for simultaneous measurement of the 25-hydroxy metabolites of vitamin $\mathrm{D}_{2}$ and $\mathrm{D}_{3}$. Clin Chem 51:1683-1690

21. Smith DC, Johnson CS, Freeman CC, Muindi J, Wilson JW, Trump DL (1999) A Phase I trial of calcitriol (1,25-dihydroxycholecalciferol) in patients with advanced malignancy. Clin Cancer Res 5:1339-1345

22. Muindi JR, Peng Y, Wilson JW, Johnson CS, Branch RA, Trump DL (2007) Monocyte fructose 1,6-bisphosphatase and cytidine deaminase enzyme activities: potential pharmacodynamic measures of calcitriol effects in cancer patients. Cancer Chemother Pharmacol 59:97-104

23. Chung I, Karpf AR, Muindi JR, Conroy JM, Nowak NJ, Johnson CS, Trump DL (2007) Epigenetic silencing of CYP24 in tumorderived endothelial cells contributes to selective growth inhibition by calcitriol. J Biol Chem 282:8704-8714

24. Lee HJ, Muindi JR, Tan W, Wilding G, Ford LA, Sait SNJ, Block AW, Barcos M, Vigil CE, Griffiths EA, Thompson JE, Wang ES, Johnson CS, Trump DL, Wetzler M (2010) Subnormal Vitamin D Levels Are Associated with Adverse Outcome In NewlyDiagnosed Similarly-Treated Adult Acute Myeloid Leukemia (AML) Patients Proc 52 ${ }^{\text {nd }}$ ASH meeting 2010 Abstract \# 1041

25. Trump DL, Chadha MK, Sunga AY, Fakih MG, Ashraf U, Silliman CG, Hollis BW, Nesline MK, Tian L, Tan W, Johnson CS (2009) Vitamin D deficiency and insufficiency among patients with prostate cancer. BJU Int 104:909-914

26. Yao S, Sucheston LE, Millen AE, Johnson CS, Trump DL, Nesline MK, Davis W, Hong CC, McCann SE, Hwang H, Kulkarni S, Edge SB, O'Connor TL, Ambrosone CB (2011) Pretreatment serum concentrations of 25-hydroxyvitamin $\mathrm{D}$ and breast cancer prognostic characteristics: a case-control and a case-series study. PLoS One 28;6 (2):e17251

27. Glendenning P, Chew GT, Seymour HM, Gillett MJ, Goldswain PR, Inderjeeth CA, Vasikaran SD, Taranto M, Musk AA, Fraser WD (2009) Serum 25-hydroxyvitamin D levels in vitamin Dinsufficient hip fracture patients after supplementation with ergocalciferol and cholecalciferol. Bone 45:870-875

28. Bacon CJ, Gamble GD, Horne AM, Scott MA, Reid IR (2009) High-dose oral vitamin D3 supplementation in the elderly. Osteoporos Int 20:1407-1415

29. Himmelstein S, Clemens TL, Rubin A, Lindsay R (1990) Vitamin $\mathrm{D}$ supplementation in elderly nursing home residents increases 25(OH)D but not $1,25(\mathrm{OH})_{2} \mathrm{D}$. Amer J Clin Nutr 52:701-706

30. Masuda S, Okano T, Kamao M, Kanedai Y, Kobayashi T (1997) A novel high-performance liquid chromatographic assay for vitamin D metabolites using a coulometric electrochemical detector. J Pharmaceut Biomedl Anal 15:1497-1502

31. Higashi T, Awada D, Shimada K (2001) Determination of 24,25dihydroxyvitamin D3 in human plasma using liquid chromatography-mass spectrometry after derivatization with a Cookson-type reagent. Biomed Chromatogr 15:133-140

32. Slominski A, Semak I, Zjawiony J, Wortsman J, Li W, Szczesniewski A, Tuckey RC (2005) The cytochrome P450scc system opens an alternate pathway of vitamin $\mathrm{D}_{3}$ metabolism. FEBS J 272:4080-4090

33. Guryev O, Carvalho RA, Usanov S, Gilep A, Estabrook RW (2003) A pathway for the metabolism of vitamin D3: unique hydroxylated metabolites formed during catalysis with cytochrome P450scc (CYP11A1). Proc Natl Acad Sci U S A 100:14754-14759

34. Pettifor JM, Bikle DD, Cavaleros M, Zachen D, Kamdar MC, Ross FP (1995) Serum levels of free 1,25-dihydroxyvitamin D in vitamin D toxicity. Ann Intern Med 122:511-513

35. White P, Cooke N (2000) The multifunctional properties and characteristics of vitamin D-binding protein. TEM 11:320-327

36. Haddad JG (1995) Plasma vitamin D-binding protein (GC-globulin): multiple tasks. J Steroid Biochem Mol Biol 53:579-582 